\section{American rock}

\section{Euan Nisbet}

Regional Stratigraphy of North America. By William J. Frazier and David R. Schwimmer. Plenum: 1987. Pp.719. $\$ 110$ (North America), \$132 (elsewhere).

How does one describe an entire continent? There are two ways. One way is to skip across the land, describing only the interesting bits and broadly dismissing the rest with a few scathing comments - "We visited Europe and saw the Queen, the Botticellis and Athens: over the rest it always rains or there is smog". On the other hand, it is possible to take a deep breath, gather information for decades and then produce a vast but inevitably very much dated compilation - "Europe stretches from Ireland, soon to be given home rule if Mr Gladstone succeeds in his legislative plan ... to [700 pages later] . . . Constantinople, the seat of the Sublime Porte which rules the Turkish Empire". Frazier and Schwimmer have chosen the latter approach. Theirs is an enormous compilation of assorted stratigraphic minutiae which, collectively, describe the fabric of the geology of North America.

The book ploughs steadily through the history of the continent, from the early Archaean to the present. The treatment of the Archaean and Proterozoic is brief: less than a hundred pages, despite the temporal span and geographical importance of these eons. But this is mostly a Phanerozoic book. As such it is an extraordinary compilation, with the crucial and critical proviso that it is a summary of the geological literature as it stood in about 1980 or 1981. Perhaps it is impossible for so vast a work to be more up to date: no doubt writing it was rather like painting the Forth Bridge - once one end is done the other is already beginning to rust again.

All the familiar stratigraphy is here, from our own old favourites in the Williston basin to a splendid collection of oddities across the land. There's a whole indigestible meal of formations, from the Pumpernickel to the Pepper and the Coffee (and of course the Shoo Fly), which give rise, naturally, to the Belcher and the Two Medicine formations to undo the damage. Should they prove inadequate or induce nightmares of a bestiary of Wild Cow and Womble formations, solace is no doubt to be had from the wisdom of the Zoroaster Granite or an appeal via the mercy of the Vishnu and Brahma Schists to be allowed the ultimate nirvana of the Zilch Formation. Details, details, details, all listed in a fine set of indexes and an appendix. Perhaps the closest comparison is with the Geological Survey of Canada's fine but aged compilation of Canadian geology. Sadly, there is no discussion whatever of the advances in the past few years in understanding basin evolution.

Yet there is a valuable place for this book. Most North American geology students, struggling to pass the "Historical Geology of North America" with a decent $\mathrm{B}-$, will be delighted with it, and with its innumerable tables, columns and helpful palaeontological details. Not for them to soar the heights of speculation (and immediately to be shot down) but rather the commonplace of drilling holes in the Kaskaskia. Should they wish to know in detail the lateral equivalent of the Duperow Formation they will undoubtedly have some local up-to-date paper, but it would be helpful to keep Frazier and Schwimmer in the exploration trailer anyway. Out of date and expensive the book may be, but it's still well worth having.

Euan Nisbet is a Professor in the Department of Geological Sciences, University of Saskatchewan, Saskatoon, Saskatchewan S7N 0W0, Canada.

\section{Pursuing annual subscriptions}

\section{Anthony Watkinson}

Journal Publishing: Principles and Practice. By Gillian Page, Robert Campbell and Jack Meadows. Butterworths: 1987. Pp.184. £27, \$79.95.

For scientists, formal publication of the results of their research is as important as carrying out the research itself. In most disciplines the refereed paper remains the main mode of communication. Most scholars also do their time on editorial boards, and in spite of the cuts in science budgets in many countries, and the commercialization of research throughout the world, refereeing the work of one's peers is still seen as an obligation to the community.

Nevertheless it is the common experience of publishers that the process of compiling, producing and selling journals is little understood. Even journal editors of long standing are sometimes profoundly ignorant about what, from the point of view of the publisher, are key aspects of the operation - for example, the fact that subscription rates have to be determined some six months before the year concerned and that page budgets must be set even earlier. Where scientists come together in committees, or as groups making decisions about journals publishing, the consequences of such lack of knowledge can be serious. Long established journals have collapsed and promising ideas have never been realized because of mistakes that could have been avoided.
The intended readership of this book is "the great many people concerned with journals publishing... whose experience of it is necessarily limited". It can be said, with qualifications, that in under 200 rather expensive pages, the greater part of the information that one could expect to find is available and reasonably easy to retrieve.

The authors are all British, and parochialism sometimes shows through. For example, the chapter on marketing is rather thin. Publicity people will be surprised at the lack of emphasis on getting sample copies to potential subscribers, which, in the United States, can often be achieved from a booth at the big congresses where the world's biggest market is conveniently gathered together. And given the intended audience, more space should have been given to a detailed analysis of contracts between learned societies and publishing companies or (as sometimes happens these days) other societies with publishing arms.

The book has probably suffered by the circumstances of its writing. It is no secret that the main author ended up doing most of the work, as is often the case in such collaborations, and the plea in the preface for feedback to enable the next edition to be better is a genuine one. By its nature the book was not going to be exciting, but the presentation does not help. The lines are too long for the print size, and the style of writing is on the dry side with an overabundance of colons and semi-colons.

For all that, Journal Publishing will be the standard reference book in its field because of the thoroughly commonsensical way in which it is written. It explains what is actually done, and why, and electronic publishing in all its meanings is kept in its place. So many books about aspects of publishing are written by those who would wish things to be other than they are

Anthony Watkinson is head of journal publish ing at Oxford University Press, Walton Street, Oxford $O X 26 D P, U K$.

\section{New in paperback}

- Memoir of a Thinking Radish by Peter Medawar, who died last year. Publisher is Oxford University Press, price is $£ 4.95$. For review see Nature 320, 647 (1986).

- The Dilemmas of an Upright Man: Max Planck as Spokesman for German Science by $\mathrm{J}$. L. Heilbron. Publisher is University of California Press, price is $\$ 7.95, £ 4.50$. For review see Nature 324, 190 (1986).

- The Mediterranean Was a Desert: A Voyage of the Glomar Challenger by Kenneth J. Hsü, an informal account of a deep-sea drilling cruise. Publisher is Princeton University Press, price is $\$ 8.95, £ 5.60$. For review see Nature $\mathbf{3 0 6}$, 507 (1983)

- Detectors for Particle Radiation by Konrad Kleinknecht. Publisher is Cambridge University Press, price is $£ 10.95, \$ 19.95$. For review see Nature 325, 586 (1987). 